\title{
Quality Investing: the Role of Profitability to Separate Good From Bad Stock in Value Investing
}

\author{
${ }^{1}$ Dr. Yanuar Dananjaya BSc., MM , ${ }^{2}$ Renna Magdalena S.T., S.E., M.Ak.
}

Universitas Pelita Harapan Surabaya

\begin{abstract}
This paper examines how company measurement of profitability can be used to enhance the return of value investing strategy. In value investing strategy, stocks that are deemed cheap based on certain measurement are purchased. It is expected that the price of cheap stocks will increase in the future, and thus resulting in high return. In the heart of this strategy is the assumption that investors overreact to bad news. Thus bad news of a company will result in reduction of stock price below its fundamental value, resulting in undervaluation of the stock. The problem with this strategy is that not all cheap stocks are undervalued. Some cheap stocks are genuinely problematic, and their cheap valuation is already reflecting the fair value of the stocks. Thus portfolio formed using value investing might contain cheap stocks that are not undervalue, but instead fairly valued in that cheap level. One way to screen fairly valued cheap stock is by using profitability measurement as addition to value measurement. In this way stocks that are chosen are cheap stocks of the company with high profitability, and thus enhancing the probability of undervalued stocks. In this research, it is found that adding ROIC to the usual PER factor in value investing strategy increases that one year portfolio return. Quality investing, in which profitability measurement is added to value measurement in value investing, is thus a potential strategy to be used by investor
\end{abstract}

Keywords: Value Investing, Quality Investing, PER, ROIC, Stock Return

\section{Introduction}

Various research has shown that stocks with lower (higher) P/E Ratio will result in higher (lower) abnormal return in the future. Early work is done by Basu (1977). The phenomena of lower (higher) P/E Ratio stocks result in higher (lower) abnormal return in the future is explained by De Bondt and Thaler (1985) as result from investor overreaction. Positive news about the company will result in overreaction from investor that will bid the stock price above its fair value. Price above fair value will result in high P/E Ratio. When price of the stock goes down to its fair value, abnormal return will be low. Same argument with negative news. Investors will overreact to negative news about the company by selling the stocks until stock price down below its fair value, resulting in low P/E Ratio.

The effect of P/E Ratio to future return is formalized by Fama and French (1993) in Fama-French 3 Factors Model. In this model, P/E Ratio is one factor that will affect stock return. Lakonishok, Shleifer, and Vishny (1994) use the model to advocate Value Investing where stocks with low P/E Ratio is considered cheap, and thus to be bought. It is implied that there is mispricing of stock price, where stocks with low P/E Ratio have lower market price compared to their intrinsic value. Fama and French (1996) disagree with this implication. It was asserted that stocks with low P/E Ratio does not mean the market price is lower than the stock intrinsic value, and thus cannot be seen as cheap stock. Low P/E Ratio indicates that a stock is experiencing distress or problem, thus increasing the stock risk. Increased stock risk reduce stock intrinsic value. Thus low 
P/E Ratio is not indication of cheap stock, but risky stock. The argument in Fama and French (1996) is according to Efficient Market Hypothesis where it is assumed that stock market price always same as its intrinsic value. Whether P/E Ratio indicates whether a stock is cheap or expensive, or indicates whether a stock is risky or not, is part of argument whether market is efficient or not.

Various research show that value investing works. Stocks with low P/E Ratio will result in high return in the future (LaPorta et al., 1997; DeChow and Sloan 1997; Sezgin 2010; Tseng 1988; Al-Mwalla et al., 2010; Weigand and Irons 2007 among others). The results suggest that indeed low P/E Ratio is indication of cheap stocks, and purchasing them can result in higher stock return in the future. Otuteye and Siddiquee (2015) criticised the value investing strategy that depends only on P/E Ratio or other measures that solely indicates the cheapness of a stock. For value investing to be trully profitable, the strategy other than identifies merely cheap stocks must be able to identify cheap and good stock. Otuteye and Siddiquee (2015) found that investing in cheap stock after filtering the stocks profitability and financial condition results in better return.

Novy_Marx (2013) combines profitability and value to form stock portfolio. Return of the portfolio is higher compared to portfolio formed based solely on profitability alone and value alone. Additionally, return of portfolio based on profitability and value shows lower variation due to better diversification effect. Piotroski (2000) and Pitoski and So (2012) found that investment strategy combining value and profitability yield much better return compared to strategy formed solely in value.

This research aim to test the result of investment strategies in Indonesia stock market formed purely from value, purely from profitability, and combination of value and profitability. Value strategy is based on investing in stocks with low P/E Ratio. For profitability strategy, Return of Invested Capital (ROIC) is used as proxy for a company profitability.

\section{Research Problem}

1. Will portfolio formed based on low P/E Ratio result in positive return?

2. Will portfolio formed based on high ROIC result in positive return?

3. Will portfolio formed based on low P/E Ratio and high ROIC result in higher return compared to portfolio formed based on low $\mathrm{P} / \mathrm{E}$ ratio alone?

4. Will portfolio formed based on low P/E Ratio and high ROIC result in higher return compared to portfolio formed based on high ROIC alone?

\section{Literature Review}

\section{Value Investing}

Negative relation between Price to Earnings Ratio (PER) and stock return is first reported by Basu (1977). Since then the phenomena has been confirmed by various researchers. Other than PER, negative relation is also observed in other measurement of value such as Price to Book Value (PBV). Most notable is Fama and French (1993) where value is one of the factor in Fama-French three factors model. In general it is found that stocks with low valuation, as indicated by low PER or low PBV, will earn higher return compared to stocks with higher valuation. Fama and French (1993) argued that low valuation stocks indicate that the stock is experiencing distress. For example the company might face new competition or experiencing liquidity problems. Distressed stocks naturally contain higher risk. New competition might reduce company cash flow, or liquidity problem can result in bankruptcy. Due to the higher risk, investors demand higher return. Thus the negative relation between value measurement and stock return. From this point of view, higher return is simply compensation for holding stocks with higher risk.

Lakonishok, Shleifer, and Vishny (1994) argued that higher return of stocks with low valuation is not due to higher risk. They found no distress in the low valuation stocks. Instead the source of higher return in low valuation stocks is mispricing. Low valuation stocks are valued below their intrinsic value, creating 
undervaluation. As market realized the mispricing, the mispricing will be corrected and the stock price will go up, resulting in higher stock return. Similarly, stocks with high valuation are valued above their intrinsic value, creating overvaluation. As overvaluation is realized, price will drop to the fair value, resulting in low stock return. La Porta (1996) and Dechow and Sloan (1997) found that low (high) valuation stocks are due to investors extrapolate bad (good) past financial report. When extrapolation does not materialize, stock price return to its fair value creating low return for high valuation stocks and high return for high valuation stocks. La Porta (1997) also shows that high valuation stocks tend to experience negative earnings surprise, resulting in low return. Ali et al., (2003) shows that negative relation between value and return is more pronounce in stocks with higher transaction cost and less sophisticated investors. These results supports the view that the source of higher return in low valuation stock is due to mispricing. The phenomena might be related to overreaction phenomena reported by De Bondt and Thaler (1985) and De Bondt and Thaler (1987)

\section{Effect of Profitability to Stock Return}

Vuolteenaho (2002) found that stock price movement is primarily driven by changes in profitability. Fama and French (2006) found that measurement of a company profitability correlates well with stock return. Logically, high profitability will increase company value and thus increase its stock price, resulting in high return. Fama and French (2015) added profitability and investment to their original three factors model to incorporate the positive relation between profitability and stock return. Hanson and Dhanuka (2015) found that ROIC correlates positively with stock return. Ball, Gerakos, Linnainmaa, and Nikolaev (2016) confirm that profitability measurement from both gross profit and from net income are both correlate positively with stock return. However, profit measurement derived from operating profit correlate more strongly. Explanation on why profitability correlate positively to stock return possibly due to behavioral factors such as anchoring, confirmation bias, or herding behavior that makes investor underreact to information on profitability. In the subsequent period after the information is fully reflected to stock price, stock of the company with higher (lower) profitability will have higher (lower) return.

\section{Hypothesis}

Portfolio formed based on value investing strategy is known to be able to result in high return. However, it suffers from the fact that some of the stocks in the portfolio will inevitably are problematic stock that are fairly priced as low valued instead of genuinely undervalued stock. Measurement of value as PER or PBV will not be able to distinguish between the two. Here then, is the role of profitability measurement. If the company of a low valuation stock shows high profitability, then it is more likely that the stock is undervalue. If the company of a low valuation stock shows low profitability, then it is more likely that the stock is a low valuations tock that is fairly priced. Thus the following hypothesis are made:

H1: Portfolio formed based on low valuation will result in positive excess return

H2: Portfolio formed based on high profitability will result in positive excess return

H3: Portfolio formed based on combination of low valuation and high profitability will result in higher return compared to portfolio formed based solely on low valuation

H4: Portfolio formed based on combination of low valuation and high profitability will result in higher return compared to portfolio formed based solely on high profitability

\section{Method}

Sample of this research is stocks in Indonesian market that are included in KOMPAS100 index, minus stocks in financial sectors. KOMPAS100 index consist of 100 stocks that are chosen based on liquidity and market capitalization. The reason of choosing stocks in this index as sample is to avoid inactive stocks (stocks with very low transaction in extended period), a prevalent problem in Indonesian market. Stocks in financial sector are excluded because financial companies have different capital structure compared to other sectors. Stock of the companies with negative net income are also excluded because PER and ROIC of 
negative net income have no meaning. Stock components of KOMPAS100 are chosen every January and July. Research period is from 2014 to 2017. For each year, the KOMPAS100 stocks from January period are included to the sample.

Proxy used for valuation is Price to Earnings Ratio (PER). It is defined as stock price divided by Earning per Share (EPS). Proxy used for profitability is Return on Invested Capital (ROIC). It is defined as Net Operating Profit After Tax (NOPAT) divided by Invested Capital. Invested Capital itself is book value of equity plus long term liability. Proxy for stock return is the excess return above market, calculated as actual return minus market return in that particular year.

To show the effectiveness of adding profitability measure to value investing strategy, the following steps are taken. Every year, stocks from KOMPAS100 in that particular year are shorted based on PER from lowest to highest. Each stock is then assigned a number. 1 for the lowest PER, 2 for the second lowest, etc. Let's call it PER number. Same process is done based on ROIC, but shorting is done from highest to lowest. We get also ROIC number. Note that the lower the number for PER number and ROIC number, theoretically the better for stock return. We also define PER-ROIC number as PER number plus ROIC number.

PER number, ROIC number, and PER-ROIC number are regressed against excess return to ascertain whether rank based on PER and ROIC has effect to excess return. Next, for each year, three types of portfolios are made:

1. Portfolio containing 20 lowest PER number, ROIC number, and PER-ROIC number

2. Portfolio containing 20 highest PER number, ROIC number, and PER-ROIC number

3. Portfolio containing all sample from that particular year.

Each year, the result of the portfolios are compared to determine which one result in the highest expected return in the next year.

\section{Result and Discussion}

After excluding stocks from financial industry and companies with negative net income, number of sample in 2014 is 66 stocks, in 2015 is 62 stocks, in 2016 is 81 stocks, and in 2017 is 71 stocks. Result of the regressions are as follow

Table 1: Regression result of independent variables to Stock Excess Return

\begin{tabular}{|l|l|c|c|c|}
\cline { 2 - 4 } \multicolumn{1}{c|}{} & \multicolumn{1}{|c|}{$\begin{array}{c}\text { Independent } \\
\text { Variable }\end{array}$} & Coef & Sig & $\begin{array}{c}\text { R squared / adjusted } \\
\text { R squared }\end{array}$ \\
\hline Regression 1 & PER number & -0.167 & 0.005 & 0.024 \\
\hline Regression 2 & ROIC number & -0.183 & 0.002 & 0.030 \\
\hline Regression 3 & PER number & -0.137 & 0.022 & \multirow{2}{*}{0.045} \\
\cline { 2 - 4 } & ROIC number & -0.157 & 0.009 & 0.048 \\
\hline Regression 4 & PER-ROIC number & -0.227 & 0.000 & 0.04 \\
\hline
\end{tabular}

Table 1 shows that PER number and ROIC number individually correlate negatively with excess stock return. It is as expected as low PER number meaning stocks with low PER, while low ROIC number meaning stocks with high ROIC. When both are regressed together, both are significant with negative coefficient. Adjusted R-squared is increased to 0.045. Interestingly, when PER number and ROIC number are combined into PER-ROIC number, R-squared is even higher compared to regression with PER number and ROIC number (regression 3). It suggests that combining PER number and ROIC number to short stocks for portfolio is more effective compared to sorting twice using PER and ROIC.

Excess return of each year portfolio is as follow 
Table 2: Next year excess return of various portfolio

\begin{tabular}{|c|c|c|c|c|c|c|c|}
\cline { 2 - 8 } \multicolumn{1}{c|}{} & $\begin{array}{c}\text { 20 lowest } \\
\text { PER number }\end{array}$ & $\begin{array}{c}\text { 20 highest } \\
\text { PER number }\end{array}$ & $\begin{array}{c}\text { 20 lowest } \\
\text { ROIC number }\end{array}$ & $\begin{array}{c}\text { 20 highest } \\
\text { ROIC number }\end{array}$ & $\begin{array}{c}\text { 20 lowest PER } \\
\text { ROIC number }\end{array}$ & $\begin{array}{c}\text { 20 highest PER- } \\
\text { ROIC number }\end{array}$ & \multirow{2}{*}{ All sample } \\
\hline $\mathbf{2 0 1 4}$ & $-9.6 \%$ & $-18.9 \%$ & $-9.0 \%$ & $-33.9 \%$ & $-7.8 \%$ & $-28.1 \%$ & $-16.8 \%$ \\
\hline $\mathbf{2 0 1 5}$ & $17.9 \%$ & $-9.5 \%$ & $15.9 \%$ & $6.7 \%$ & $15.1 \%$ & $-4.1 \%$ & $7.0 \%$ \\
\hline $\mathbf{2 0 1 6}$ & $-25.2 \%$ & $-26.9 \%$ & $-9.5 \%$ & $-29.9 \%$ & $-18.1 \%$ & $-30.2 \%$ & $-23.2 \%$ \\
\hline $\mathbf{2 0 1 7}$ & $-12.0 \%$ & $-12.7 \%$ & $-4.1 \%$ & $-11.4 \%$ & $4.7 \%$ & $-14.9 \%$ & $-9.3 \%$ \\
\hline
\end{tabular}

Table 2 shows the performance of various portfolio in 2014, 2015. 2016, and 2017. Every year, the excess return of portfolio formed from 20 lowest PER number, 20 lowest ROIC number, and 20 lowest PER-ROIC number beats the corresponding portfolio of 20 highest number. The result confirms that PER number, ROIC number, and PER-ROIC number affect the next period excess return. Compared to all samples results, only PER number in 2016 and 2017 fail to perform better than the all samples result. It shows that investment strategy using PER number, ROIC number, and PER-ROIC number has potential to be used by investors.

Table 3: Return difference between portfolios and all sample return

\begin{tabular}{|c|c|c|c|}
\cline { 2 - 4 } \multicolumn{1}{c|}{} & PER number & ROIC number & PER-ROIC number \\
\hline $\mathbf{2 0 1 4}$ & $7.2 \%$ & $7.8 \%$ & $9.0 \%$ \\
\hline $\mathbf{2 0 1 5}$ & $10.9 \%$ & $8.9 \%$ & $8.1 \%$ \\
\hline $\mathbf{2 0 1 6}$ & $-1.9 \%$ & $13.8 \%$ & $5.2 \%$ \\
\hline $\mathbf{2 0 1 7}$ & $-2.6 \%$ & $5.3 \%$ & $14.1 \%$ \\
\hline average & $\mathbf{3 . 4 \%}$ & $\mathbf{8 . 9} \%$ & $\mathbf{9 . 1 \%}$ \\
\hline
\end{tabular}

Table 3 shows the following year return difference between portfolios formed using 20 stocks with lowest PER number, lowest ROIC number, and lowest PER-ROIC number compared to return from all samples portfolio in 2014, 2015, 2016, and 2017. Performance of portfolio formed from 20 stocks with lowest PER number beats all samples portfolio averagely $3.4 \%$ per year. For portfolio of 20 stocks with lowest ROIC number, the result is even better at $8.9 \%$. The best result is in portfolio of lowest PER-ROIC number at $9.1 \%$.

\section{Conclusion and Recommendation}

Both PER and ROIC of a company affect its future stock return and can be used as investment strategy resulting in superior return. Combining those PER and ROIC to a single factor results in a new investment strategy superior than strategy based on PER alone or ROIC alone. The source of the ability of this strategy in generating high return probably due to the use of ROIC to screen out problematic companies with low PER. This research only utilize sample from KOMPAS100 stocks, and only for 4 years period. Next research can expand the sample to all stocks in Indonesian stock market and using longer time period to confirm the result.

\section{References}

[1] Al-Mwalla, M., Al-Omari, A. M., \& Ayad, F. (2010). The relationship between P/E ratio, dividend yield ratio, size and stock returns in Jordanian companies: A co-integration approach. International Research Journal of Finance and Economics, 49(7), 87-103.

[2] Ball, R., Gerakos, J., Linnainmaa, J. T., \& Nikolaev, V. (2016). Accruals, cash flows, and operating profitability in the cross section of stock returns. Journal of Financial Economics, 121(1), 28-45.

[3] Basu, S. (1977). Investment performance of common stocks in relation to their price - earnings ratios: A test of the efficient market hypothesis. The journal of Finance, 32(3), 663-682.

[4] De Bondt, W. F., \& Thaler, R. (1985). Does the stock market overreact?. The Journal of finance, 
40(3), 793-805.

[5] De Bondt, W. F., \& Thaler, R. H. (1987). Further evidence on investor overreaction and stock market seasonality. The Journal of finance, 42(3), 557-581.

[6] Dechow, P. M., \& Sloan, R. G. (1997). Returns to contrarian investment strategies: Tests of naive expectations hypotheses. Journal of financial economics, 43(1), 3-27.

[7] Fama, Eugene F., and Kenneth R. French, 1993, Common risk factors in the returns on bonds and stocks, Journal of Financial Economics 33, 3-53.

[8] Fama, E. F., \& French, K. R. (1996). Multifactor explanations of asset pricing anomalies. The journal of finance, 51(1), 55-84.

[9] Fama, E. F., \& French, K. R. (2015). A five-factor asset pricing model. Journal of financial economics, 116(1), 1-22.

[10] Hanson, D., \& Dhanuka, R. (2015). The "science" and "art" of high quality investing. Journal of Applied Corporate Finance, 27(2), 73-86.

[11] Lakonishok, J., Shleifer, A., \& Vishny, R. W. (1994). Contrarian investment, extrapolation, and risk. The journal of finance, 49(5), 1541-1578.

[12] Novy-Marx, R. (2013). The other side of value: The gross profitability premium. Journal of Financial Economics, 108(1), 1-28.

[13] Otuteye, E., \& Siddiquee, M. (2015). Overcoming cognitive biases: A heuristic for making value investing decisions. Journal of Behavioral Finance, 16(2), 140-149.

[14] Piotroski, J. D. (2000). Value investing: The use of historical financial statement information to separate winners from losers. Journal of Accounting Research, 1-41.

[15] Piotroski, J. D., \& So, E. C. (2012). Identifying expectation errors in value/glamour strategies: A fundamental analysis approach. The Review of Financial Studies, 25(9), 2841-2875.

[16] Porta, R. L., Lakonishok, J., Shleifer, A., \& Vishny, R. (1997). Good news for value stocks: Further evidence on market efficiency. The Journal of Finance, 52(2), 859-874.

[17] Weigand, R. A., \& Irons, R. (2007). The market p/e ratio, earnings trends, and stock return forecasts. The Journal of Portfolio Management, 33(4), 87-101.

[18] Vuolteenaho, T. (2002). What drives firm - level stock returns?. The Journal of Finance, 57(1), 233264. 